\title{
Problematika Pendamping Desa Profesional dalam Pemberdayaan Masyarakat Desa di Kota Padangsidimpuan
}

\author{
Icol Dianto \\ Institut Agama Islam Negeri Padangsidimpuan \\ Email: icoldianto@iain-padangsidimpuan.ac.id
}

\begin{abstract}
Professional village facilitators are facilitators who provide assistance to the community. Its presence is the demand of Law Number 6 of 2014 concerning Villages and the regulation of the village minister No. 3 of 2015 concerning Village Assistance. Four years of village funds and village assistance programs are running, but there have not been many changes. This condition is affected by the problems experienced by professional village assistants. This research was conducted in the City of Padangsidimpuan using a qualitativedescriptive method, found four aspects of the problematic professional village assistants. First the Quantity Aspect: looking at the problems that arise due to the quantity of power available. Both Quality Aspects: there are still professional village assistants with educated schools that have a good, incompatible scientific background with fields of empowerment and community assistance and lack of education and training.
\end{abstract}

Abstrak: Pendamping desa profesional adalah fasilitator yang melakukan pendampingan kepada masyarakat. Kehadirannya adalah tuntutan UndangUndang Nomor 6 Tahun 2014 Tentang Desa dan Permendes No 3 Tahun 2015 Tentang Pendampingan Desa. Empat tahun program dana desa dan pendampingan desa berjalan, namun belum banyak perubahan. Kondisi ini dipengaruhi oleh problematika yang dialami oleh pendamping desa profesional. Penelitian ini dilakukan di Kota Padangsidimpuan dengan menggunakan metode kualitatif-deskriptif, ditemukan aspek utama problematika pendamping desa profesional. Pertama Aspek. Kuantitas: melihat persoalan-persoalan yang muncul disebabkan oleh faktor kuantitas tenaga yang tersedia. Kedua Aspek Kualitas: masih ada pendamping desa profesional berpendidikan sekolah menangah, ketidaksesuaian latarbelakang keilmuan dengan bidang kerja pemberdayaan dan pendampingan masyarakat dan minimnya pendidikan dan pelatihan.

Kata Kunci: Pendamping Desa, Pemberdayaan Masyarakat, Problematika. 


\section{PENDAHULUAN}

Desa merupakan pemerintah terkecil yang diakui dalam sistem ketatanegaraan Indonesia. Keberadaan desa diatur berdasarkan konstitusi. Undang-Undang Nomor 5 Tahun 1979 Tentang Pemerintahan Desa merupakan peraturan perundang-undangan yang pertama mengatur secara khusus tentang desa. Pada hakikatnya, peraturan dan perundangan-undangan tentang desa merupakan upaya pemerintah untuk mempercepat kemajuan pembangunan sumber daya manusia dan pembangunan sumber daya alam di wilayah nusantara ini. Persoalan pembangunan yang lebih diketahui oleh masyarakat bawah mendorong pemerintah membuka kran yang seluas-luasnya untuk menampung aspirasi masyarakat. Pemerintah memandang pemerintahan desa lebih tepat untuk melaksanakan pembangunan yang kemudian dikenal dengan bottom up. Oleh karena itu, pelaksanaan pembinaan dan pemberdayaan masyarakat desa menjadi kewenangan pemerintah desa.

Kementerian Desa, Pembangunan Daerah Tertinggal dan Transmigrasi (Kemen Desa PDT'T) merupakan kementerian yang mengelolah pembangunan, pembinaan dan pemberdayaan desa. Sejak tahun 2015, telah mengucurkan dana desa dalam jumlah besar. Alokasi dana yang besar itupun diikuti dengan melakukan rekrutmen pendamping desa profesional secara berjenjang mulai dari provinsi, kabupaten, kecamatan dan desa. Pendamping desa profesional yang melakukan kegiatan pendampingan kepada pemerintah desa dan masyarakat bertugas memfasilitasi masyarakat untuk mandiri dan aktif dalam pembangunan. Kegiatan pendampingan desa merupakan kegiatan memfasilitasi dan mendampingi masyarakat desa dalam penyelenggaraan pemerintahan desa, pelaksanaan pembangunan, melakukan pembinaan dan pemberdayaan masyarakat desa.

Pada Program Pembangunan dan Pemberdayaan Masyarakat Desa (P3MD) Kemen Desa PDTT, mengutip definisi pemberdayaan masyarakat pada UU No.6/2014 tentang Desa, dijelaskan bahwa pemberdayaan masyarakat desa yang harus dilakukan oleh tenaga pendamping profesional desa sebagai berikut:

Pemberdayaan masyarakat desa adalah upaya mengembangkan kemandirian dan kesejahteraan masyarakat dengan meningkatkan pengetahuan, sikap, keterampilan, perilaku, kemampuan, kesadaran, serta memanfaatkan sumber daya melalui penetapan kebijakan, program, kegiatan, dan pendampingan yang sesuai dengan esensi masalah dan prioritas kebutuhan masyarakat desa. (Kemendesa, 2014: 4).

Berdasarkan definisi di atas, dapat dipahami bahwa konsep pendampingan masyarakat yang ditawarkan oleh Kemendesa PDTT menginginkan adanya 
tenaga pendamping profesional yang betul-betul profesional, independen, kritis dan transformatif. Tenaga pendamping profesional bukan pengelola proyek pembangunan di desa dan bukanlah melakukan kontrol dan "mobilisasi partisipasi" terhadap warga desa untuk menjalankan prosedur kerja yang sudah dirancang berdasar pada kepentingan dari luar desa. Kerja pendampingan lebih tepat dimaknai sebagai proses fasilitasi terhadap warga desa agar berdaya dalam memperkuat desanya sebagai komunitas yang memiliki pemerintahannya sendiri (self governing community).

Komite Pemantau Pelaksana Otonomi Daerah (Tribunnews.com, 2017) merilis laporan bahwa banyak kepala desa yang mengeluhkan kinerja pendamping desa karena kualifikasi tenaga pendamping masyarakat tidak sesuai dengan kompetensi yang diharapkan oleh pemerintah desa. Pada dasarnya ada dua persoalan tenaga pendamping profesional desa ini terlihat pada faktor kuantitas dan kualitas. Secara kuantitas, pendamping desa tentu saja belum sebanding dengan jumlah desa di Indonesia. Kondisi ini juga dirasakan oleh Pemerintah Kota Padangsidimpuan. Afdhal, Kepala Bidang Pemerintahan Desa Dinas Pemberdayaan Masyarakat dan Desa Kota Padangsidimpuan menyebutkan bahwa satu pendamping lokal desa membina lima desa (Afdhal, 2017). Tidak seimbang jumlah tenaga pendamping desa dengan jumlah desa berdampak pada tidak efektifnya kerja pendamping desa, sebagaimana yang diharapkan oleh undang-undang. Sementara itu, persoalan kualitas berhubung erat dengan kualifikasi/ kompetensi tenaga pendamping profesional desa. Kemen Desa PDT'T memberikan peluang besar untuk putraputri daerah menjadi tenaga pendamping desa masyarakat. Pada rekrutmen tenaga pendamping desa tahun 2017, untuk Pendamping Lokal Desa (PLD) membolehkan kualifikasi pendidikan tamatan Sekolah Menengah Atas (SMA) sederajat. Konsep mengakomodir putra-putri daerah itu bagus namun perlu pertimbangan kompetensi. Apalagi di saat ini, sudah banyak para sarjana yang menetap di desa masing-masing.

Data menunjukan masih banyak desa yang gagal dalam mengelolah keuangan desa. Hal ini diungkapkan oleh Menteri Desa, Pembangunan Daerah Tertinggal, dan Trasnmigrasi, Eko Putro Sandjojo pada Rapat Kerja Nasional I Dewan Pimpinan Pusat (DPP) Perkumpulan Aparatur Pemerintah Desa Seluruh Indonesia, (PAPDESI) di Asrama Haji Donohudan Boyolali, Jawa Tengah, Rabu, 13 Desember 2017 lalu. (Sandjojo, 2017). Selain itu, kegagalan desa mengelolah Badan Usaha Milik Desa (BUMDes) juga menjadi indikator atas kinerja tenaga pendamping profesional desa yang diprogramkan oleh 
Kemen Desa PDTT. Berdesa （Berdesa.com, 2017) merilis terdapat lima faktor penyebab BUMDesa gagal dalam membangun bisnis. Pertama, salah memilih ide bisnis. Pada umumnya BUMDesa memilih ide bisnis yang sedang tren dan ketat persaingan, dan kejenuhan pasar. Kedua, kegagalan dalam mengakses sumber daya yang sebenarnya sudah tersedia tetapi tidak tahu cara mengakses sumber daya (potensi) tersebut. Ketiga, salah mengambil keputusan, tidak bekerja cerdas, dan tidak bertindak secara efektif. Keempat, tidak mampu mengelola bisnis dengan baik dan benar mulai dari masalah keuangan, produksi, kualitas, dan sumber daya manusia. Kelima, kalah bersaing dengan produk lain.

Berdasarkan permasalahan di atas, dapat dipahami bahwa terjadi beberapa kemungkinan yang menjadi faktor kegagalan tersebut. Penulis mengidentifikasi beberapa persoalan yang mungkin terjadi pada tenaga pendamping profesional desa sebagai berikut; minimnya pendanaan, terbatasnya akses penggunaan dana desa yang sudah memiliki petunjuk teknis dan petunjuk pelaksanaan dari Kementerian, rendahnya sumber daya aparatur pemerintahan desa, masyarakat dan pendamping profesional desa sehingga tidak mampu menggali potensi desa.

Persoalan yang dijelaskan di atas menggelitik kegelisahan akademik penulis. Latar belakang penulis sebagai akademisi pengembangan masyarakat Islam, merasa terpanggil untuk meneliti persoalan pendamping desa tersebut, khususnya pendamping masyarakat desa bidang pemberdayaan masyarakat. Untuk mengetahui lebih rinci permasalahan tersebut, maka dirasa penting untuk diadakan penelitian mengenai bagaimana problematika tenaga pendamping profesional pemberdayaan masyarakat desa di Kota Padangsidimpuan.

\section{METODE ANALISIS}

Metode analisis dalam artikel ini adalah metode kualitatif dengan jenis deskriptif. Adapun alasan pemilihan metode dan jenis penelitian tersebut, karena penulis ingin mengungkap fenomena sosial yang terjadi pada suatu kelompok. Rachmat Kriyantono dalam bukunya Riset Komunikasi （Kriyantono, 2007: 58) menuliskan bahwa penelitian kualitatif bertujuan untuk menjelaskan fenomena dengan sedalam-dalamnya melalui pengumpulan data sedalamdalamnya. Nazir, (1983:43) menjelaskan penelitian deskriptif adalah suatu metode dalam meneliti status sekelompok manusia, suatu objek, suatu set kondisi, suatu sistem pemikiran, ataupun suatu kelas peristiwa pada masa sekarang. Arikunto (2007: 234). menyebutkan bahwa penelitian deskriptif adalah penelitian yang dimaksudkan untuk mengumpulkan informasi mengenai status 
suatu gejala yang ada, yaitu keadaan gejala menurut apa adanya pada saat penelitian dilakukan.

Adapun sumber data primer dalam penelitian ini adalah sumber dan pemegang kunci informasi (key informan) purposive sampling maksudnya sampel yang ditetapkan yaitu tenaga pendamping desa profesional tingkat kabupaten/kota, kecamatan dan desa, dan stake holder/ organisasi pemerintah daerah.

\section{KAJIAN TEORITIS \\ Profesi dan Profesional}

Profesi berbeda dengan pekerjaan meski profesi merupakan suatu pekerjaan. Pekerjaan adalah aktivitas menyelesaikan sesuatu dan membuat sesuatu dengan mempergunakan tenaga, pikiran dan keterampilan tertentu. Sementara itu, profesi adalah layanan-layanan tertentu yang dilakukan berdasarkan ilmu pengetahuan tertentu yang telah melembaga dengan baik.

A profession delivers esoteric services base on esoteric knowledge systematically formulated and applied to the needs of a clien. Every profession considers it self the proper body to set the terms in which some aspect of society, life or nature is to be thought of and to define the general lines or even the details of public police concerning it. (Wirawan, 2012: 268).

Dari definisi yang dikemukakan oleh Wirawan tersebut, didapatkan indikator-indikator suatu pekerjaan dikategorikan sebagai profesi, sebagai berikut:

a. A profession delivers esoteric services maksudnya adalah suatu profesi menyajikan layanan-layanan.

b. Base on esoteric knowledge maksudnya layanan yang dilakukan itu harus berdasarkan pengetahuan tertentu yang dimiliki oleh orang-orang tertentu. Jadi, sebuah profesi itu tidak hanya memerlukan keterampilan dan pengalaman saja tetapi harus ada atau wajib menggunakan teori-teori yang dikaji oleh lembaga pendidikan melalui pelatihan dan penelitian.

c. Proper body to set the terms maksudnya profesi itu sebagai lembaga rujukan untuk mengatur sejumlah aspek kehidupan masyarakat dan kebijakan publik mengenai sesuatu.

\section{Pendamping Profesional Pemberdayaan Masyarakat}

Pendamping masyarakat merupakan istilah yang lebih disukai di kalangan pekerja sosial, khususnya mereka yang melakukan sejumlah pekerjaan pengembangan masyarakat. Istilah pendamping masyarakat diartikan lebih sebagai 'teman sejajar' atau 'mitra masyarakat' ketimbang 'petugas' yang berkonotasi bekerja untuk lembaganya dengan melaksanakan tugas di lapangan. 
Edi Soeharto menyebut pekerja sosial ini dengan sociater (Suharto, 2014). Selain pendamping masyarakat, istilah fasilitator masyarakat (community facilitator) juga digunakan sebagai alternatif dari pendamping masyarakat. Hal ini sejalan dengan perkembangan kegiatan pengembangan masyarakat yang lebih menekankan pada partisipasi dan pemberdayaan masyarakat. Fasilitator menggambarkan bahwa pekerja pendamping masyarakat itu berperan sebagai pendorong, penggerak, katalisator dan motivator masyarakat.

Pendamping profesional pemberdayaan masyarakat adalah orang/ lembaga yang melakukan tugas pendampingan dalam kegiatan pemberdayaan masyarakat dengan berdasarkan ilmu pengetahuan, keterampilan dan pengalaman di bidang pemberdayaan. Dalam perkembangannya, tenaga pendamping pemberdayaan masyarakat tidak harus mendapatkan pengetahuan akademik melalui jenjang pendidikan formal seperti ilmu pengembangan masyarakat dan ilmu kesejahteraan dan pekerjaan sosial. Paham ini dikenal dengan aliran kompetensi (competence movement). Menurut Jim Ife, kelompok ini memiliki fokus pada penempatan kompetensi sebagai komponen utama dalam menentukan tenaga kerja yang dibutuhkan oleh lembaga pemerintahan/ organisasi swasta (Rukminto Adi, 2008). Dasar dari gerakan kompetensi ini adalah untuk memasarkan ide bahwa suatu pekerjaan harus didefinisikan berdasarkan kompetensi yang dibutuhkan dan bukan sekadar berdasarkan pada kualifikasi formal dari pelamar. Masih menurut paham ini, kualifikasi kompetensi yang didapatkan dari suatu pelatihan ataupun pengalaman kerja sebelumnya kadangkala dapat lebih memperlihatkan kompetensi seseorang, bila dibandingkan dengan gelar akademik (pendidikan formal) yang dimiliki pelamar kerja.

\section{Kualifikasi tenaga pendamping masyarakat desa}

Kualifikasi tenaga pendamping pemberdayaan masyarakat desa memiliki acuan baku yang dirumuskan oleh Tim Persiapan Lembaga Sertifikasi Profesi Fasilitator Pemberdayaan Masyarakat yang difasilitasi oleh Kementerian Dalam Negeri bersama-sama dengan British Council (Sumpeno, 2009). Adapun kualifikasi yang dimaksud digolongkan kepada tiga kompetensi, yakni kompetensi umum, kompetensi inti dan kompetensi khusus.

Adapun kompetensi umum meliputi kualifikasi yang dibutuhkan oleh semua fasilitator, yaitu:
a. Membangun relasi sosial.
b. Mengoptimalkan pemanfaatan sumber daya masyarakat.
c. Menyadarkan kebutuhan masyarakat.
d. Melaksanakan fasilitasi pembelajaran. 
e. Meningkatkan aksesibilitas antar pemangku kepentingan.

f. Membangun visi dan kepemimpinan.

Sementara itu, unit kompetensi inti meliputi :

a. Membangun jejaring dan kemitraan.

b. Membangun modal sosial.

c. Membangun kapasitas kelembagaan masyarakat dan pemerintahan.

d. Memperkuat posisi tawar.

e. Merancang perubahan.

f. Mendesain proses pembelajaran.

g. Menyiapkan kader pemberdayaan masyarakat.

h. Mengembangkan kemandirian masyarakat.

i. Meningkatkan aksesibilitas antar pemangku kepentingan.

j. Mengelola konflik.

k. Mengembangkan sistem sanksi reward and punishment.

Selanjutnya, unit kompetensi khusus yang harus dimiliki oleh seorang tenaga pendamping pemberdayaan masyarakat desa adalah (1) mengembangkan ide, metoda, produk baru di bidang/ sektor kegiatan tertentu. (2) memfasilitasi penerapan ide, metoda, produk baru di bidang/sektor kegiatan tertentu.

\section{Memberdayakan Masyarakat}

Istilah pemberdayaan lahir dari kata bahasa Inggris yaitu empower yang artinya memberi kuasa atau wewenang kepada (orang lain). Ife mengartikan pemberdayaan, "Empowerment means providing people with the resources, opportunities, knowledge, and skill to increase their capacity to determine their own future, and to participate in and effect of their community. (Sjafari dan Nugroho, 2012: 12). Pendapat ini ditranslit oleh Nanang Martono mengartikan bahwa pemberdayaan adalah menyiapkan kepada masyarakat sumber daya, kesempatan/ peluang, pengetahuan dan keahlian untuk meningkatkan kapasitas diri masyarakat itu dalam menentukan masa depan mereka serta untuk berpartisipasi dan mempengaruhi kehidupan dalam komunitas masyarakat itu sendiri (Martono, 2011). Program pemberdaaan masyarakat merupakan sebuah proses panjang yang dilakukan secara berjenjang dan berkelanjutan, sehingga tidak mungkin dicapai dalam waktu yang relatif singkat dan cepat (Sugiarso, 2017: 347).

World Bank (2001) mengartikan pemberdayaan sebagai upaya untuk memberikan kesempatan dan kemampuan kepada kelompok masyarakat (miskin) untuk mampu dan berani bersuara (voice) atau menyuarakan pendapat, ide atau gagasan-gagasannya serta kemampuan dan keberanian untuk memilih (choice) sesuatu (konsep, metode, produk, tindakan, dll) yang terbaik bagi pribadi, keluarga dan masyarakatnya. Huraerah (1997: 96) merangkum pendapat para ahli 
mengenai pemberdayaan, sebagai berikut, pemberdayaan berasal dari bahasa Inggris yaitu empowerment yang secara harfiah bisa diartikan sebagai pemberkuasaan dalam arti pemberian atau peningkatan "kekuasaan" (power) kepada masyarakat yang lemah atau tidak beruntung (disadvantaged). Empowerment aims to increase the power of disadvantaged, demikian menurut Jim Ife. Swift dan Levin mengatakan pemberdayaan menunjuk pada usaha realocationof power melalui perubahan struktur sosial. Selanjutnya, Rappaport mengungkapkan pemberdayaan adalah suatu cara dengan mana rakyat mampu menguasai (berkuasa atas) kehidupannya. Craig dan Mayo mengatakan bahwa konsep pemberdayaan termasuk dalam pengembangan masyarakat dan terkait dengan konsep-konsep kemandirian (selfhelp), partisipasi (participation), jaringan kerja (networking) dan pemerataan (equity).

Upaya memberdayakan masyarakat dapat dilihat dari tiga sisi, yaitu:

1) Menciptakan suasana atau iklim yang memungkinkan potensi masyarakat berkembang (enabling).

2) Memperkuat potensi atau daya yang dimiliki masyarakat (empawering).

3) Memberdayakan mengandung pula arti melindungi (advokasi). Maksudnya, dalam proses pemberdayaan harus dicegah yang lemah menjadi bertambah lemah karena kekurangberdayaan dalam menghadapi yang kuat. (Theresia et al, 2014:119-120).

Penjelasan di atas dapat dipahami bahwa suatu kegiatan dapat dikatakan sebagai kegiatan pemberdayaan jika mengandung tiga unsur pokok, yakni enabling, empowering dan advokasi. Banyak institusi yang mengklaim melaksanakan kegiatan pemberdayaan masyarakat, namun mengabaikan tiga unsur itu. Dengan adanya batasan tersebut, maka jelaslah mana kegiatan pemberdayaan dan mana kegiatan yang bukan pemberdayaan masyarakat.

\section{KEORGANISASIAN PENDAMPING DESA PROFESIONAL Struktur Organisasi Pendamping Desa Profesional P3MD Kota Padangsidimpuan}

Kerja pendampingan desa diatur dalam Peraturan Menteri Desa Nomor 3 Tahun 2015 tentang Pendampingan Desa. Dalam peraturan itu, pendamping desa profesional terdiri dari Tenaga Ahli Pemberdayaan Masyarakat, Pendamping Teknis, Pendamping Desa dan Pendamping Lokal Desa. Hierarki organisasi pendamping desa profesional di Kota Padangsidimpuan berbeda dengan Permendes. Dalam Permendes disebutkan bahwa Tenaga Ahli itu berkedudukan di Pusat atau Provinsi, sedangkan pendamping teknis yang 
seharusnya berkedudukan di Kabupaten/Kota. Akan tetapi, pendamping desa profesional tertinggi di Sekretariat P3MD Kota Padangsidimpuan dinamai dengan Tenaga Ahli bukan Pendamping Teknis. Sementara itu, kader pemberdayaan masyarakat desa yang berkedudukan di desa, dalam struktur keorganisasian P3MD Kota Padangsidimpuan dikenal dengan Pendamping Lokal Desa (PLD). Adanya perubahan-perubahan istilah dari penamaan tenaga pendamping desa mempengaruhi pada pemahaman personal dalam mengemban tugas yang telah diamanatkan oleh peraturan perundang-undangan. Kondisi ini dapat memicu munculnya kesalahan dalam memahami, melaksanakan tugas dan fungsi serta kewenangan dari pendamping desa.

Pendamping desa profesional dalam menjalankan keorganisasian, memiliki satu kantor sekretariat Program Pembangunan dan Pemberdayaan Masyarakat Desa (P3MD) beralamat di Kecamatan Padangsidimpuan Batunadua Kota Padangsidimpuan. Kantor sekretariat ini menjadi pusat pertemuan, rapat evaluasi dan koordinasi pendamping desa profesional, yang dikomando oleh Tenaga Ahli Pemberdayaan Masyarakat Desa Mohammad Solah. Pendamping desa di tingkat kecamatan dan desa berkewajiban dating satu kali dalam satu bulan ke sekretariat untuk mengikuti rapat koordinasi, evaluasi kerja pendampingan dan pembuatan laporan. Selain itu, mereka juga berkewajiban datang pada waktu dan kegiatan tertentu, yang diadakan di sekretariat (Solah, 2018). Dalam pertemuan dengan pendamping desa kecamatan, pendamping lokal desa diberi pembinaan terkait pelaksanaan tugas lapangan. Selain itu, ada rapat koordinasi di tingkat kota bersama tenaga ahli. Dalam rapat koordinasi itu, yang paling sering dibicarakan adalah kendala-kendala pendamping lokal desa dan pendamping desa kecamatan dalam melaksanakan tugas pendampingan di lapangan (Akhir, 2018).

Adapun personil pendamping desa professional Sekretariat P3MD Kota Padangsidimpuan terdiri dari empat orang tenaga ahli berkedudukan di level kota, pendamping desa pemberdayaan dan teknik infrastruktur berjumlah 10 orang berkedudukan di kecamatan, dan pendamping lokal desa berjumlah 11 orang dengan wilayah kerja level desa.

\section{Kegiatan Pemberdayaan Masyarakat/Desa P3MD}

Program pendampingan dan pemberdayaan desa yang dilakukan oleh pendamping desa profesional berkaitan erat dengan kegiatan-kegiatan yang dibiayai oleh instansi pemerintahan daerah dan pemerintah desa. Kegiatan yang dilakukan itu bersifat program rutin instansi terkait. Adapun kegiatan yang dilaporkan oleh pendamping desa profesional di Kota Padangsidimpuan, berdasarkan laporan bulan Mei 2018, maka ditemukan lima kegiatan: pelatihan 
perangkat desa, pelatihan sistem keuangan desa, pelatihan TPK, pelatihan paralegal dan pelatihan kader posyandu.

Target kerja pendampingan desa yang dibebankan kepada pendamping desa P3MD adalah untuk memastikan berjalannya program dana desa mulai dari tahap perencanaan pembangunan desa sampai pada pelaksanaan kegiatan pembangunan desa. Secara rinci dapat dilihat pada kutipan di bawah ini:

1. Perencanaan Pembangunan Desa

a. Penyusunan Rencana Pembangunan Jangka Menengah (RPJM) Desa

- Pembentukan Tim RPJM Desa

- Penyelarasan arah kebijakan perencanaan Pembangunan dengan arah pembangunan Kabupaten

- Pengkajian Keadaan Desa (PKD)

- Laporan Hasil PKD kepada Kepala Desa

- $\quad$ Penyampaian hasil PKD oleh Kades ke BPD

- Musdes Penyusunan Rencana Pembangunan Desa

- Penyusunan Rancangan RPJM Desa oleh Tim RPJM Desa

- Musrenbang desa Pembahasan dan Penetapan Rancangan RPJM Desa

- Perbaikan RPJM Desa berdasarkan kesepakatan musrenbang desa

- Penyusunan Rancangan Peraturan Desa tentang RPJM Desa

- Rapat Keputusan Bersama Kades dan BPD untuk penetapan Perdes RPJM Desa

b. Penyusunan Rencana Kerja Pemerintah (RKP) Desa

- Musdes Penyusunan Rencana Pembangunan Desa

- Pembentukan Tim Verifikasi sesuai Jenis Kegiatan dan keahlian

- Pembentukan Tim RKP Desa

- Pencermatan Pagu Indikatif Desa dan penyelarasan program

- Pencermatan Ulang RPJM Desa

- Penyusunan Rancangan RKP Desa

- Penyusunan Usulan Pelaksana Kegiatan

- Penyusunan Rencana Kegiatan dan Rencana Anggaran Biaya

- Pelaksanaan Verifikasi oleh Tim Verifikasi

- Laporan Tim Penyusun RKP Desa kepada Kepala Desa

- Musyawarah Perencanaan untuk penetapan RKP Desa 
- Penyusunan Rancangan Peraturan Desa tentang RKP Desa

- Rapat Keputusan Bersama Kades dan BPD untuk penetapan Perdes RKP Desa

- Penyampaian Daftar usulan RKP Desa kepada Bupati melalui Camat.

2. Pelaksanaan Kegiatan Pembangunan Desa

a. Tahap persiapan

- Penetapan Pelaksana Kegiatan dengan Keputusan Kades

- Penyusunan Rencana Kerja dan ditetapkan dengan Keputusan Kades

- Sosialisasi Kegiatan

- Pembekalan pelaksana Kegiatan meliputi: Pengelolaan Keuangan Desa, Penyelenggaraan Pemerintahan Desa dan Pembangunan Desa.

- Penyiapan Dokumen Administrasi Kegiatan

- Pendataan dan Pengadaan Tenaga Kerja

- Pendataan Kebutuhan Material dan Cara Pengadaan Material.

b. Tahap Pelaksanaan Kegiatan

- Pencairan dana Tahap I dan Pelaksanaan Kegiatan

- Pemeriksaan Kegiatan Infrastruktur Tahap Pertama

- Rapat Kerja Pelaksana Kegiatan Tahap I

- Pencairan dana Tahap II dan Pelaksanaan Kegiatan

- Pemeriksaan Kegiatan Infrastruktur Tahap Kedua

- Rapat Kerja Pelaksana Kegiatan Tahap II

- Pemeriksaan Kegiatan Infrastruktur Tahap Ketiga

- Rapat Kerja Pelaksana Kegiatan Tahap III

- Penyampaian Laporan Pelaksana Kegiatan kepada Kades

- Penyusunan Laporan Penyelenggaraan Pemdes oleh Kades

- Musdes Pelaksanaan Pembangunan Desa

- Perdes tentang Pelestarian dan pemanfaatan hasil kegiatan

- Pembentukan kelompok pelestarian dan pemanfaat hasil kegiatan

- Peningkatan Kapasitas kelompok pelestarian dan pemanfaat

Kegiatan rutinitas yang dilakukan oleh pendamping lokal desa adalah melakukan kunjungan ke kantor desa untuk memantau penggunaan dana desa. Program-program yang telah dianggarkan melalui dana desa, maka itulah tugas 
pendamping lokal desa. Mulai dari tahapan perencanaan kegiatan yang berjenjang dimulai dari musyawarah masyarakat desa.

Setalah program masuk dalam Rencana Kerja Pemerintah (RKP) desa maka tahapan selanjutnya adalah pelaksanaan kegiatan baik pembangunan infrastruktur maupun pelatihan-pelatihan. Peran yang dimainkan oleh pendamping desa adalah mengenai apa yang boleh dan apa yang tidak boleh didanai oleh dana desa sedangkan untuk output kegiatan masih belum menjadi prioritas. Tahapan selanjutnya adalah evaluasi kegiatan lebih menitikberatkan pada bagaimana laporan pertanggungjawaban keuangan setiap program yang dibiayai dana desa. Pendamping lokal desa lebih fokus pada administasi pelaporan keuangan. Perhatian pendamping desa untuk keberlanjutan program/kegiatan, pencapaian target kegiatan, dan kemanfaatan yang didapatkan oleh masyarakat belum mendapatkan proporsi yang seharusnya ada dalam program pembangunan dan pemberdayaan desa/masyarakat.

\section{PROBLEMATIKA PENDAMPING DESA PROFESIONAL}

Adapun problematika pendamping pemberdayaan masyarakat desa dapat dilihat dari dua aspek utama, yaitu aspek kuantitas dan aspek kualitas. Pertama, Aspek Kuantitas. Problematika adalah persoalan yang dihadapi oleh indiividu, kelompok dan lembaga. Jika dilihat pada aspek kuantitas berarti fokus utamanya adalah menganalisis suatu persoalan dalam perspektif jumlah. Problematika pendamping pemberdayaan masyarakat desa dalam aspek kuantitas adalah melihat persoalan-persoalan yang muncul yang disebabkan oleh faktor kuantitas atau jumlah tenaga pendamping desa yang tersedia.

Pada aspek kuantitas, pendamping desa untuk Kota Padangsidimpuan tidak ideal. Konsep ideal dari kementerian desa adalah satu desa satu pendamping desa. Akan tetapi di Kota Padangsidimpuan, satu orang pendamping desa dapat mendampingi 4-8 desa. Keterbatasan kemampuan fisik pendamping desa dalam melakukan kegiatan pendampingan. Tugas utama yang dibebankan kepada pendamping lokal desa sebagaimana telah dijelaskan sebelumnya, yaitu memastikan progres kegiatan pembangunan desa. Kalau ada empat desa, maka satu pendamping desa melaksanakan tugas pengontrolan kepada empat desa dengan persoalan yang berbeda masing-masing desa. Beban kerja yang tidak sebanding dengan tenaga yang tersedia sehingga kerja pendamping lokal desa tidak dapat fokus melaksanakan tugas pendampingan pemberdayaan masyarakat. Padahal kerja pendampingan desa, tidak hanya sebatas memastikan progress kegiatan pembangunan desa melainkan ada kerja pemberdayaan untuk kemandirian dan kesejahteraan masyarakat. 
Dalam peraturan Menteri Desa telah dijelaskan perlunya melakukan kegiatan pemberdayaan kepada kelompok-kelompok masyarakat. Selain itu, ada bidangbidang yang telah ditetapkan oleh pemerintah untuk dirambah oleh kerja pendampingan desa. Hal itu tidak berjalan untuk di Kota Padangsidimpuan dan Kecamatan Padangsidimpuan Tenggara tempat penelitian ini dilakukan. Persoalan yang muncul dari perspektif aspek kuantitas di Kota Padangsidimpuan berupa eterbatasan kemampuan fisik tenaga pendamping desa profesional dalam melakukan pelayanan (pendampingan) dengan jumlah empat sampai delapan desa. Juga kurang fokus kegiatan pendampingan desa dan pemberdayaan masyarakat sehingga belum muncul kegiatan pendampingan dan pemberdayaan secara partisipatif dan berkelanjutan yang dapat menumbuhkan kesadaran, kemandirian dan kesejahteraan masyarakat/desa.

Kedua, Aspek Kualitas. Aspek kualitas mendeskripsikan penguasaan pendamping desa terhadap materi pemberdayaan. Penguasaan yang bersifat akademis dan teori-teori pemberdayaan mesti dikuasai dengan baik. Penguasaan materi pemberdayaan ini terletak pada beberapa hal, yaitu (1) tenaga pednamping desa mendapatkan materi pemberdayaan melalui pendidikan formal dan (2) melalui pendidikan dan pelatihan khusus. Selain penguasaan materi, keterujian penggunaan materi dengan penyelesaian masalah yang dihadapi juga menunjukan kualitas akademis individual, yang lebih dikenal dengan pengalaman.

Dalam modul pelatihan dan penyegaran Buku 2 Lembar Informasi Pendampingan Desa disebutkan bahwa pendamping desa memiliki kompetensi sebagai berikut:

a. Mendorong partisipasi masyarakat dalam perencanaan dan pembangunan Desa yang dilaksanakan secara swakelola oleh Desa;

b. Mengembangkan program dan kegiatan pembangunan Desa secara berkelanjutan dengan mendayagunakan sumber daya manusia dan sumber daya alam yang ada di Desa;

c. Menyusun perencanaan pembangunan Desa sesuai dengan prioritas, potensi, dan nilai kearifan lokal;

d. Menyusun perencanaan dan penganggaran yang berpihak kepada kepentingan warga miskin, warga disabilitas, perempuan, anak, dan kelompok marginal;

e. Mengembangkan sistem transparansi dan akuntabilitas dalam penyelenggaraan Pemerintahan Desa dan pembangunan Desa;

f. Mendayagunakan lembaga kemasyarakatan Desa dan lembaga adat; 
g. Mendorong partisipasi masyarakat dalam penyusunan kebijakan Desa yang dilakukan melalui musyawarah Desa;

h. Menyelenggarakan peningkatan kualitas dan kapasitas sumber daya manusia masyarakat Desa;

i. Melakukan pendampingan masyarakat Desa yang berkelanjutan; dan

j. Melakukan pengawasan dan pemantauan penyelenggaraan Pemerintahan Desa dan pembangunan Desa yang dilakukan secara partisipatif oleh masyarakat Desa. (Kemendesa PDT'T, 2015).

Pemberian materi pemberdayaan ini diberikan kepada pendamping desa pada waktu pendamping desa mengikuti pendidikan dan pelatihan yang dikenal dengan pratugas. Menurut Akhir (2018), pratugas tidak cukup memadai dalam menstransfer pengetahuan pelaksanaan tugas pendampingan desa. Menurutnya masih perlu pembinaan berkelanjutan mengenai peran tugas yang akan dilaksanakan oleh pendamping desa di lapangan. Ada tiga inti pemberdayaan adalah adanya kondisi dan situasi yang memberikan peluang yang memungkinkan masyarakat untuk berkembang (enabling), terbinanya partisipasi masyarakat (participative), dan adanya jaminan keberlanjutan program pemberdayaan (sustainable). Tiga inti pemberdayaan itu sudah diakomodir dalam kompetensi pendamping desa di atas. Maslam et el menyebutkan bahwa konsep pemberdayaan untuk merubah kondisi masyarakat menjadi lebih baik berdasarkan kebutuhannya (Muslam et.el, 2017: 52).

Pada aspek kualitas, ada beberapa item yang menjadi temuan di lapangan yaitu:

a. Masih ada tenaga pendamping professional desa yang berpendidikan sekolah menangah, sementara individual, kelompok masyarakat dan lembaga yang akan didamping sudah banyak yang berpendidikan sarjana.

b. Tidak sesuainya latarbelakang keilmuan pendamping desa profesional dengan bidang kerja pendampingan dan pemberdayaan masyarakat sehingga ada kesulitan dalam pencapaian kompetensi kerja pendamping desa.

c. Minimnya pendidikan dan pelatihan yang dapat menambah wawasan, keilmuan dan penguasaan materi pemberdayaan masyarakat.

d. Membutuhkan proses dalam menginternalisasi pengetahuan sehingga pengetahuan itu menjadi kesadaran kerja sesuai bidang keilmuan pendampingan dan pemberdayaan masyarakat.

e. Selain dasar-dasar keilmuan pemberdayaan masyarakat, ada keterampilan pendukung kerja pendampingan desa yang harus dimiliki oleh pendamping desa profesional, sehingga urusan pendidikan (keilmuan) tidak terasupi oleh pendidikan saat pratugas. 
Pendapat Tenaga Ahli Pembangunan Partisipatif P3MD Kota Padangsidimpuan, Samsuddin menjelaskan bahwa sebenarnya kualitas tidak menjadi persoalan mendasar bagi pendamping desa. Materi pendampingan dapat dipelajari dan diimplementasikan secara bertahap. Mempelajari materi pendamping sambil melakukan kerja pendampingan, dengan begitu diharapkan pendamping desa mampu menerapkan pengetahuan. Akan tetapi, menurut Samsuddin, yang menjadi persoalan adalah tidak adanya tolok ukur pada kerja pemberdayaan itu. Tugas pemberdayaan masyarakat itu tidak ada alat ukur (unvariable). Karena itu tidak bisa kita menentukan tingkat keberhasilan. Apa ukuran kegiatan permberdayaan dikatakan berhasil, itu tidak jelas. (Samsuddin, 2018).

Mencermati penjelasan tenaga ahli pembangunan partisipatif di atas, terkait dengan tolok ukur keberhasilan kerja pemberdayaan sudah tertuang pada kompetensi bagi pendamping desa. Kompetensi dirumuskan untuk menjawab tugas yang akan diemban oleh pendamping desa profesional. Dengan kata lain, kerja pendampingan dapat dikatakan berhasil apabila standar kerja kompetensi pendampingan desa tercapai, yaitu meningkatnya partisipasi masyarakat dalam perencanaan dan pembangunan desa, terpogram kegiatan pembangunan desa secara berkelanjutan, tersusun dokumen perencanaan pembangunan desa sesuai dengan prioritas, potensi, dan nilai kearifan lokal, tersusun dokumen perencanaan dan penganggaran yang berpihak kepada kepentingan warga miskin, warga disabilitas, perempuan, anak, dan kelompok marginal, terwujudnya sistem transparansi dan akuntabilitas dalam penyelenggaraan pemerintahan desa dan pembangunan desa, terbinanya peran lembaga kemasyarakatan desa dan lembaga adat, terbina kesadaran masyarakat untuk berpartisipasi dalam penyusunan kebijakan desa yang dilakukan melalui musyawarah desa, terlaksana kegiatan peningkatan kualitas dan kapasitas sumber daya manusia masyarakat desa, adanya kegiatan pendampingan masyarakat desa yang berkelanjutan; dan, terlaksananya kegiatan pengawasan dan pemantauan penyelenggaraan pemerintahan desa dan pembangunan desa yang dilakukan secara partisipatif oleh masyarakat desa.

\section{Pembagian Kerja Pendampingan}

Pendamping desa profesional memiliki tugas yang telah diatur secara jelas dalam Permendesa Nomor No. 3 Tahun 2015 Tentang Pendampingan Desa. Ada pendampingan berjenjang tingkat desa, kecamatan, dan kabupaten/kota. Temuan di lapangan, semakin rendah tingakatan pendampingan desa semakin luas bidang kerja pendampingan yang dilakukan. Pada sisi lain, pendamping desa profesional pada tingkat paling rendah yaitu desa, mendapatkan insentif 
pekerjaan yang paling kecil. Sumber-sumber penghasilan tambahan bagi pendamping desa di level paling bawah bahkan tidak ada. Persoalan ekonomi menjadi faktor pendukung dalam melaksanakan suatu aktivitas, meski tidak semua aktivitas manusia dapat diukur dengan materi (uang). Fakta bahwa kegagalan kerja pendampingan desa profesional, seperti yang ada dalam Permendesa No. 3/2015 itu, disebabkan karena pembagian kerja yang tidak berimbang di antara pendamping desa dan ketidakberimbangan beban kerja dengan honor yang diterima.

Mengatasi persoalan ini, mesti ada pembagian kerja yang jelas antara pendamping desa pemberdayaan dan pendamping desa teknik infrastruktur dengan pendamping lokal desa. Pendamping lokal desa mestinya tidak mengurus masalah anggaran dana desa, dan tidak melakukan pengawasan pelaksanaan dana desa, melainkan ia mestinya fokus pada kompetensi pemberdayaan masyarakat. Mengenai teknis infrastruktur sudah ada pendamping desa teknik infrastruktur (PDTI) untuk melakukan pendampingan ke pemerintah desa, sedangkan Pendamping Desa Pemberdayaan (PDP) dapat melakukan kerja pendampingan desa dengan kepala desa untuk menyusun rencana dan mengawasi pelaksanaan pembangunan desa pemberdayaan dan pembangunan partisipatif di tingkat kecamatan. Sementara itu, pendamping lokal desa berfokus pada masyarakat, bukan pada pemerintah desa. Masih banyak kelompok masyarakat yang mestinya dapat diberi penyuluhan oleh pendamping desa lokal. Pemberdayaan itu terkait dengan mempersiapkan sumberdaya manusia, menciptakan peluang, memberi pengetahuan dan memberikan keterampilan bagi masyarakat sehingga masyarakat dapat aktif dalam menyelesaikan persoalan hidupnya.

Merujuk pada teori-teori pemberdayaan, maka dapatlah dipilah bahwa perlu ada pembagian tugas yang jelas antara pendamping desa dengan pendamping lokal desa, yang wilayah kerjanya sama yaitu desa. Khusus untuk tenaga pendamping desa pemberdayaan dan teknik infrastruktur barangkali sesuai dengan tingkatannya dianggap lebih mahir dari pendamping lokal desa, maka ia melaksanakan tugas-tugas advokasi dan koordinasi dengan pemerintahan desa, sedangkan pendamping lokal desa khusus bersentuhan dengan masyarakat desa. Dengan adanya pembagian kerja dan fokus kerja, maka kehadiran pendamping desa terasa lebih bermanfaat bagi masyarakat dan pemerintah desa. Untuk posisi saat ini, hasil penelitian menunjukan bahwa pendamping desa dan pendamping lokal desa fokus bersentuhan kerja dengan pemerintah desa, sehingga sudah memasuki tahun keempat program dana desa dan pendampingan masyarakat dan desa, yang pola pikir dan kesadaran masyarakat belum menunjukan perubahan yang signifikan. Peran pendamping desa profesional sebagai 
penyuluh masyarakat tidak sebatas menyampaikan inovasi saja, melainkan ia harus mampu menjembati antara pemerintah/ lembaga pemberdayaan/ donatur dalam menyampaikan umpan balik/ tanggapan masyarakat kepada pemerintah/ lembaga pemberdayaan/ donatur yang bersangkutan. Peran mediasi/fasilitasi mendominasi kerja agen perubahan masyarakat, ia mampu melaksanakan tugas membantu masyarakat untuk memperbaiki kesejahteraannya dan pada sisi lain ia memperoleh kepercayaan sebagai agent of change yang dapat diterima dan dipercaya masyarakat penerima manfaat (Dianto, 2018: 96).

Problematika yang dihadapi oleh pendamping desa terkait dengan peran pendamping desa yang belum sesuai dengan peran pendampingan dalam konteks bidang pemberdayaan masyarakat. Apapun peran yang akan diberikan kepada pendamping desa dan pendamping lokal desa, namun sepanjang objek pendampingan dapat dibedakan sehingga ada fokus kerja masing-masing. Kelemahan fokus kerja ini sebenarnya sudah disadari baik Tenaga Ahli yang mengkoordinir pendamping desa maupun oleh pendamping desa dan lokal desa itu sendiri.

Masalah pendamping desa terkait belum tersentuhnya subtansial dari pemberdayaan itu. Pada umumnya tenaga pemberdayaan lokal kita baru bisa menjalankan praktis administrasi sehingga sifatnya prosedural administrasi saja, sementara subtansi pemberdayaan seperti keberlanjutan, proses penyadaran dan progres kegiatan belum tersentuh. Masalah ini disebabkan karena tugas fasilitator hanya sebatas penyambung informasi dari kementerian desa kepada pemerintah desa. (Samsuddin, 2018).

Penjelasan di atas memberi gambaran bahwa kegiatan pendampingan desa baru mampu menyentuh hal-hal yang bersifat administratif dan prosedural, belum menyentuh subtantif dari kegiatan pemberdayaan. Oleh karena itu, perlu ada kegiatan yang menyentuh subtantif pemberdayaan, yaitu suatu upaya untuk memandirikan masyarakat, bagaimana menolong masyarakat untuk mampu menolong dirinya sendiri (Warjiyati, 2017: 178).

\section{Koordinasi}

Problematika yang dihadapi oleh pendamping desa profesional selanjutnya adalah masalah koordinasi. Keahlian yang harus dimiliki oleh pendamping desa terkait dengan kemampuan komuniasi dan negosiasi. Dua kemampuan ini memiliki peran penting dalam menjalankan fungsi koordinasi. Tenaga ahli/pendamping teknis desa harus mampu membangun hubungan koordinasi yang baik dengan pemerintah daerah dan dinas/lembaga yang mengurus desa. Tidak terbina koordinasi yang baik, maka ada dua kemungkinan yaitu kemahiran dalam berkomunikasi dan teknik negosiasi. 
Masalah ketiga yang dialami oleh pendamping desa adalah masalah koordinasi. Bicara tentang desa tidak lepas pembicaraan terkait dana desa. Dana desa merupakan hak otoritas pemerintah desa. Kami dari fasilitator hanya memfasilitasi tentang bagaimana cara menggunakan dana desa yang benar, membuat perencanaan, melaksanakan program dan pertanggungjawaban anggaran. (Samsuddin, 2018).

Masalah koordinasi ini seringkali mengenai proses pengesahan anggaran pendapatan dan belanja daerah kota padangsidimpuan yang seringkali terlambat dari target penggunaan dana desa yang diberikan oleh Kementerian Desa. Terlambatnya pengesahan anggaran tentu mengganggu penyerapan dana desa. Seringkali mendekati akhir semester pertama tiap tahun, pagu anggaran definitif untuk dana desa belum diketahui oleh pihak pendamping desa.

Data penelitian menjelaskan bahwa ada indikasi yang memperkuat bahwa sulitnya koordinasi antara pendamping lokal desa dengan pendamping desa yang ditunjuk sebagai koordinator kecamatan.

Pendamping lokal desa dan pendamping desa pada pelaksanaan tugas lapangan ini, kami sebenarnya sama. Terkadang pendamping desa juga turun ke desa, meski secara aturan mereka memiliki wilayah kerja di tingkat kecamatan. Koordinasi mereka dengan pemerintah kecamatan. Akan tetapi untuk keperluan tertentu mereka juga turun ke desa melakukan koordinasi dengan pemerintah desa. (Akhir, 2018).

Penjelasan dari pendamping lokal desa itu memberi gambaran bahwa pendamping desa yang tidak kaku hanya menjalin koordinasi dengan pemerintah kecamatan saja melainkan juga melakukan koordinasi dan kerja pendampingan ke pemerintah desa dalam hal tugas tertentu, seperti merancang desain pembangunan infrastruktur, pembuatan laporan keuangan, dan lain-lain.

Selain permasalahan keterlambatan pengesahan anggaran, koordinasi pendamping desa kepada kepala desa hanyalah formalitas saja sementara keputusan pelaksanaan dana desa berada pada kepala desa. Pendamping desa hanya memfasilitasi cara penggunaan dana desa yang baik dan benar sesuai dengan peraturan yang berlaku. Maka tidak heran ketika kepala desa merasa terganggu dengan saran-saran pendamping desa, bias saja kepala desa mengabaikan saran tersebut dan bahkan menganggap pendamping desa tidak jauh beda dengan oknum lembaga swadaya masyarakat yang kerjanya menakuti kepala desa.

\section{KESIMPULAN}

Pendamping desa profesional adalah fasilitator yang melakukan pendampingan kepada masyarakat. Kehadirannya adalah tuntutan Undang- 
Undang Nomor 6 Tahun 2014 Tentang Desa dan Permendes No 3 Tahun 2015 Tentang Pendampingan Desa. Empat tahun program dana desa dan pendampingan desa berjalan, namun belum banyak perubahan. Kondisi ini dipengaruhi oleh problematika yang dialami oleh pendamping desa profesional. Penelitian ini dilakukan di Kota Padangsidimpuan dengan menggunakan metode kualitatif-deskriptif, ditemukan empat aspek problematika pendamping desa profesional.

Pertama Aspek Kuantitas: melihat persoalan-persoalan yang muncul disebabkan oleh faktor kuantitas tenaga yang tersedia ditermukan keterbatasan kemampuan fisik tenaga pendamping desa profesional dalam melakukan pelayanan pendampingan dan kurang fokus kegiatan pemberdayaan masyarakat yang dapat menumbuhkan kesadaran, kemandirian dan kesejahteraan masyarakat. Kedua Aspek Kualitas: penguasaan pendamping desa terhadap materi pemberdayaan, akademis dan teori-teori pemberdayaan melalui pendidikan formal dan melalui pendidikan dan pelatihan khusus. Temuan lapangan terkait aspek kualitas yaitu masih ada pendamping desa profesional berpendidikan sekolah menangah, tidak sesuainya latarbelakang keilmuan dengan bidang kerja pemberdayaan dan pendampingan masyarakat, minimnya pendidikan dan pelatihan, keilmuan dan penguasaan materi pemberdayaan dan pendampingan masyarakat, butuh proses untuk internalisasi pengetahuan.

Ketiga Aspek Pembagian Kerja Pendampingan menemukan bahwa kesuksesan program kerja pendampingan desa profesional dipengaruhi oleh pembagian kerja dan ketidakberimbangan beban kerja dengan honor yang diterima. Aspek Koordinasi maksudnya tenaga ahli/pendamping teknis desa belum maksimal membangun hubungan koordinasi dengan pemerintah daerah sehingga kebijkankebijakan untuk mendukung program pendampingan belum tersedia.

\section{DAFTAR PUSTAKA}

Arikunto, Suharsimi. 2007. Manajemen Penelitian. Jakarta: Rineka Cipta.

Agus Salim. 2006. Mengolah Data Dalam Penelitian Kualitatif, "http://atwarbajari.wordpress.com/2009/04/18/ mengolah-data-dalampenelitian-kualitatif/ (akses 15 November 2017).

Dianto, Icol, Peranan Dakwah Dalam Proses Pengembangan Masyarakat Islam, Jurnal Hikmah (5) 1, Juni 2018.

Hasan, Iqbal. 2002. Metodologi Penelitian. Indonesia: Ghalia.

http://artikata.com/arti-362279-berdaya.html 
http:// kemendesa.go.id/view/detil/2274/tiga-tahun-dana-desa-turunkanangka-kemiskinan-di-desa

http://www.berdesa.com/kesalahan-penyebab-kegagalan-bumdesa/

Huraerah, Abu. 1997. Pengorganisasian dan Pengembangan Masyarakat. Bandung: Humaniora.

Kamus Besar Bahasa Indonesia, "Arti Kata Daya," http://bahasa.cs.ui.ac.id/kbbi/kbbi.php?keyword=daya\&varbidang=all\& vardialek $=$ all\&varragam $=$ all \&varkelas $=$ all\&submit $=$ tabel $\quad($ akses 17 November 2017)

Kriyantono, Rachmat. 2007. Riset Komunikasi. Jakarta: Kencana.

Mardikanto, Totok dan Poerwoko Soebianto. 2010. Pemberdayaan Masyarakat dalam Perspektif Kebijakan Publik. Jakarta: Penerbit Alfabeta.

Martono, Nanang. 2011. Sosiologi Perubahan Sosial: Perspektif Klasik, Modern, Posmodern, dan Poskolonial. Jakarta: Rajawali Press.

Muslam et.el, Pemberdayaan Raudlatul Athfal (RA) melalui Peningkatan Kualitas SDM Guru di Daerah Nelayan Kecamatan Tugu Kota Semarang, DIMAS (17) 1, Mei 2017.

Nazir, Moh. 1983. Metode Penelitian. Bogor: Ghalia Indonesia.

Rukminto Adi, Isbandi. 2008. Intervensi Komunitas dan Pengembangan Masyarakat. Jakarta: PT RajaGrafindo Persada.

Sjafari, Agus dan Kandung Sapto Nugroho. 2012. Perubahan Sosial: Sebuah Bunga Rampai. Serang: FISIP Untirta.

Sugiarso, Agus Riyadi, Rusmadi, Pemberdayaan Masyarakat Melalui Pemanfaatan Tanah Pekarangan (PTP) untuk Konservasi dan Wirausaha Agribisnis di Keluraban Kedung Pane Kota Semarang, DIMAS (17) 2, Nopember 2017.

Sumpeno, Wahyudin. 2009. Menjadi Fasilitator Genius. Yogyakarta: Pustaka Pelajar.

Theresia, Aprilia, et.el. 2014. Pembangunan Berbasis Masyarakat. Bandung: Alfabeta. Undang-Undang Republik Indonesia Nomor 6 Tahun 2014 Tentang Desa Warjiyati, Sri, Pemberdayaan Paralegal Aisyiyah Ranting Sukodono dalam Pendampingan Korban Kekerasan Perempuan dan Anak, DIMAS (17(2), Nopember 2017.

Widjaja, HAW.. 2010. Otonomi Desa Merupakan Otonomi Yang Asli, Bulat dan Utuh. Jakarta: PT RajaGrafindo Persada. 